\title{
Penerapan E-commerce dengan Metode Costumer Relationship Management (CRM) Berbasis Website (Studi Kasus: Gudang Distro Palembang)
}

\author{
Dona Marcallina \\ Amik Bina Sriwijaya Palembang \\ Jl Mayjen HM Ryacudu Palembang \\ donamarcelina@rocketmail.com
}

\author{
Delpiah Wahyuningsih \\ STMIK Atma Luhur Pangkalpinang \\ Jl Selindung-Kec Gabek Pangkalpinang \\ delphibabel@atmaluhur.ac.id
}

\begin{abstract}
Abstrak-- Gudang distro bergerak dibidang penjualan pakaian, dimana banyaknya pesaing yang ada di seputaran Palembang. Disini Gudang Distro mempunyai tujuan untuk membuat pelanggan puas akan produk yang di tawarkan oleh Gudang Distro. Mengingat banyaknya pesaing dan untuk memuaskan pelanggan, menerapkan sebuah sistem ECommerce dengan Costumer Relationship Management. Menurut Buttle, F, Costumer Relationship Management merupakan salah satu strategi bisnis untuk meningkatkan keuntungan, penghasilan, dan kepuasan konsumen dengan cara mengatur segmentasi konsumen, cara memberikan perlakuan terhadap konsumen, dan mengimplementasikan proses customer-centric. Penerapan e-commerce berbasis website pada Gudang Distro dimaksudkan dengan tujuan mempermudah pembeli didalam melakukan proses pembelian dan memudahkan Gudang Distro dalam promosi produk, laporan jual beli produk.
\end{abstract}

Kata kunci-E-Commerce, Costumer Relationship Management, Gudang Distro

\section{PENDAHULUAN}

Saat ini dalam dunia teknologi berkembang dengan sangat pesat. Terutama dalam bidang pemasaran serta penjualan. Banyak perusahaan yang membutuhkan wadah untuk memasarkan produk yang mereka miliki. Baik secara online di website maupun berbasis android.

Dengan perkembangan teknologi tersebut memacu stakeholder untuk bergerak dan membuat inovasi untuk produk yang mereka tawarkan. Salah satu terapan produk untuk di pasarkan baik secara online melalui website maupun berbasis android adalah menargetkan pelanggan agar puas terhadap layanan penjualan serta sistem yang menarik dan mudah digunakan untuk pelanggan.

Disini Gudang Distro akan menerapkan sebuah sistem penjualan online dengan berbasis costumer relationship management. Penerapan penjualan dan pembelian secara online pada Gudang Distro dimaksudkan dengan tujuan mempermudah pembeli didalam melakukan proses pembelian dan memudahkan admin dalam mencetak Laporan serta penerapan website ini juga dimaksudkan sebagai media Promosi. Transaksi Penjualan dan pembelian pada Gudang Distro ini awalnya masih dilakukan secara manual yaitu pembeli datang langsung ke Gudang Distro, Tentunya hal itu menjadi permasalahan,Untuk mengatasi hal tersebut maka penting untuk mengubah sistem manual menjadi system pembelian secara online dengan tujuan untuk memudahkan penggunjung memesan secara online sehingga penggujung tidak perlu datang lagi ke Gudang Distro dan dapat memperluas pengembangan penjualan pada gudang distro tersebut. Serta memudahkan pemilik gudang ditro untuk mengetahui laporan hasil penjualan.

Ada beberapa penelitian yang terkait dengan menggunakan costumer relationship management (crm). Hasil dari penelitian ovi dyantina, dkk menghasilkan pada sistem informasi pemasaran yang sedang berjalan masih terdapat kelemahan-kelemahan terutama pada proses penyampaian informasi promosi dan sistem yang diusulkan sudah memenuhi kebutuhan dan mempunyai keunggulan yaitu terintegrasi dengan sistem yang berkaitan dengan sistem informasi pemasaran.

Masalah yang dipertimbangkan yaitu bagaimana membuat suatu sistem penjualan online dengan metode CRM (Costumer Relationship Management) objek penelitian Gudang Distro Palembang?

Adapun tujuan penelitian adalah:

1) Dapat mempermudah proses transaksi Penjualan dan pembelian secara online

2) Mampu memenuhi kebutuhan pelanggan tentang informasi produk terlaris, produk terbaru serta produk yang sedang mendapat potongan harga yang ada pada gudang distro palembang.

3) Dapat mempermudahkan proses pengelolahan data produk dan pembuatan laporan. 
4) Mempermudah pemilik gudang distro Palembang dalam mempromosikan produk yang diakan dijual pada gudang distro Palembang.

\section{LANDASAN TEORI}

\section{A. Costomer Relationship Management}

Costomer Relationship Mangement adalah salah satu strategi bisnis untuk meningkatkan keuntungan, penghasilan, dan kepuasan konsumen dengan cara mengatur segmentasi konsumen, cara memberikan perlakuan terhadap konsumen, dan mengimplementasikan proses customercentric. [1]

Pengertian lain mengatakan bahwa ia adalah sebuah sistem informasi yang terintegrasi yang digunakan untuk merencanakan, menjadwalkan, dan mengendalikan aktivitas-aktivitas prapenjualan dan pascapenjualan dengan sebuah organisasi. CRM melingkupi semua aspek yang berhubungan dengan calon pelanggan dan pelanggan saat ini, termasuk di dalamnya adalah pusat panggilan (call center), tenaga penjualan (sales force), pemasaran, dukungan teknis (technical support) dann layanan lapangan (field service). Sebuah sistem CRM harus bisa menjalankan fungsi [4]:

- Mengidentifikasi faktor-faktor yang penting bagi pelanggan.

- Mengusung falsafah customer-oriented (customer centric)

- Mengadopsi pengukuran berdasarkan sudut pandang pelanggan

- Menyediakan dukungan pelanggan yang sempurna

- Menangani keluhan/komplain pelanggan

- Mencatat dan mengikuti semua aspek dalam penjualan

- Membuat informasi holistik tentang informasi layanan dan penjualan [2].

\section{METODE PENELITIAN}

Metedologi yang digunakan dalam pengembangn sistem adalah metodologi Protyping. Metodologi Prototyping merupakan salah satu metode pengembangan perangat lunak yang banyak digunakan Dengan metode prototyping ini pengembang dan pelanggan dapat saling berinteraksi selama proses pembuatan sistem. Sering terjadi seorang pelanggan hanya mendefinisikan secara umum apa yang dikehendakinya tanpa menyebutkan secara detail output apa saja yang dibutuhkan, pemrosesan dan data-data apa saja yang dibutuhkan.

\section{A. Tahapan dalam Prototype:}

1) Pengumpulan kebutuhan.

Pelanggan dan pengembang bersama-sama mendefinisikan format seluruh perangkat lunak, mengidentifikasikan semua kebutuhan, dan garis besar sistem yang akan dibuat.

2) Membangun prototype
Membangun prototype dengan membuat perancangan sementara yang berfokus pada penyajian kepada pelanggan (misalnya dengan membuat input dan format output)

3) Evaluasi protoptype

Evaluasi ini dilakukan oleh pelanggan apakah prototype yang sudah dibangun sudah sesuai dengan keinginann pelanggan. Jika sudah sesuai maka langkah d akan diambil. Jika tidak prototype direvisi dengan mengulangu langkah $\mathrm{a}, \mathrm{b}$, dan $\mathrm{c}$.

4) Mengkodekan system

Dalam tahap ini prototype yang sudah disepakati diterjemahkan ke dalam bahasa pemrograman yang sesuai.

5) Menguji system

Setelah sistem sudah menjadi suatu perangkat lunak yang siap pakai, harus dites dahulu sebelum digunakan.Pengujian ini dilakukan dengan White Box, Black Box, Basis Path, pengujian arsitektur dan lain-lain.

6) Evaluasi Sistem

Pelanggan mengevaluasi apakah sistem yang sudah jadi sudah sesuai dengan yang diharapkan .Jika ya, langkah 7 dilakukan; jika tidak, ulangi langkah 4 dan 5 .

7) Menggunakan system

Perangkat lunak yang telah diuji dan diterima pelanggan siap untuk digunakan.

B. Notasi yang digunakan dalam sistem

Notasi yang digunakan untuk menggambarkan atau mendesaian proses pengembangan sistem menggunakan Unified Modeling Language (UML) [3].

\section{Sistem yang sedang berjalan}

Berdasarkan hasil pengamatan dan analisis yang dilakukan di Gudang Distro Palembang terdapat prosedural transaksi penjualan masih secara manual. Dimana pelanggan datang ke Gudang distro untuk membeli produk yang ingin dibeli. Masalah transaksi penjualan juga terbatas hanya melayani pelanggan wilayah itu saja. Dengan kata lain transaksi penjualan pada Gudang distro tidak melayani ke kota lain. Masalah tersebut yang akan dikembangkan kedalam sebuah sistem penjualan. Ada beberapa permasalahan yang dihadapi didalam sistem yang sedang berjalan saat ini diantaranya:

- Proses pemasaran dilakukan dengan memajang barang didalam Distro.

- Proses transaksi terhadap konsumen dilakukan secara langsung, sehingga harus memakan waktu dan biaya .

- Pemberian informasi terhadap konsumen yang berhubungan dengan Distro dan produk yang dijual hanya dapat terjadi pada saat dilokasi Distro.

- Penentuan barang yang akan diproduksi masih manual, dimana proses permintaan produksi barang dilakukan dengan melihat berkas laporan penjualan dan stok barang yang sedang ada. 
- Kurangnya Promosi Produk Pada Guadng Ditro Tersebut

\section{Sistem yang di ajukan}

Dari sistem yang sedang berjalan di atas maka dapat mengajukan sistem yang akan dibuat. Adapun karakteristik dari sistem yang diajukan adalah pengunjung, pelanggan, administrator dan pimpinan. Dimana semua pengguna mempunyai karakterisktik penggunaan yang berbeda diantaranya:

Tabel 1. Karakteristik Pengguna

\begin{tabular}{|c|c|}
\hline Pengguna & Kegiatan \\
\hline Pengunjung & $\begin{array}{l}\text { Melihat produk tetapi tidak dapat } \\
\text { melakukan transaksi pembelian. } \\
\text { Pengunjung ini adalah semua orang yang } \\
\text { telah masuk ke website Gudang Distro } \\
\text { Palembang tapi belum melakukan login. }\end{array}$ \\
\hline Pelanggan & $\begin{array}{l}\text { Pengguna sistem yang dapat melihat } \\
\text { produk, dan dapat melakukan transaksi } \\
\text { pembelian. Pelanggan ini adalah semua } \\
\text { pengunjung yang telah mendaftar } \\
\text { terlebih dahulu dan melakukan login } \\
\text { pelanggan. }\end{array}$ \\
\hline Administrator & $\begin{array}{l}\text { Bagian administrator bertugas } \\
\text { menambah, mengedit dan menghapus } \\
\text { data produk, menghapus data pelanggan, } \\
\text { mengkonfirmasi pesanan, menghapus } \\
\text { dan menjawab faq, melihat dan laporan } \\
\text { produk terlaris serta melihat dan } \\
\text { mencetak hasil laporan penjualan, } \\
\text { mengelola dan memelihara sekaligus } \\
\text { menjaga keamanan data yang terdapat } \\
\text { pada perangkat lunak }\end{array}$ \\
\hline Pimpinan & $\begin{array}{l}\text { Melihat laporan hasil penjualan dan } \\
\text { produk terlaris }\end{array}$ \\
\hline
\end{tabular}

1) Usecase Diagram

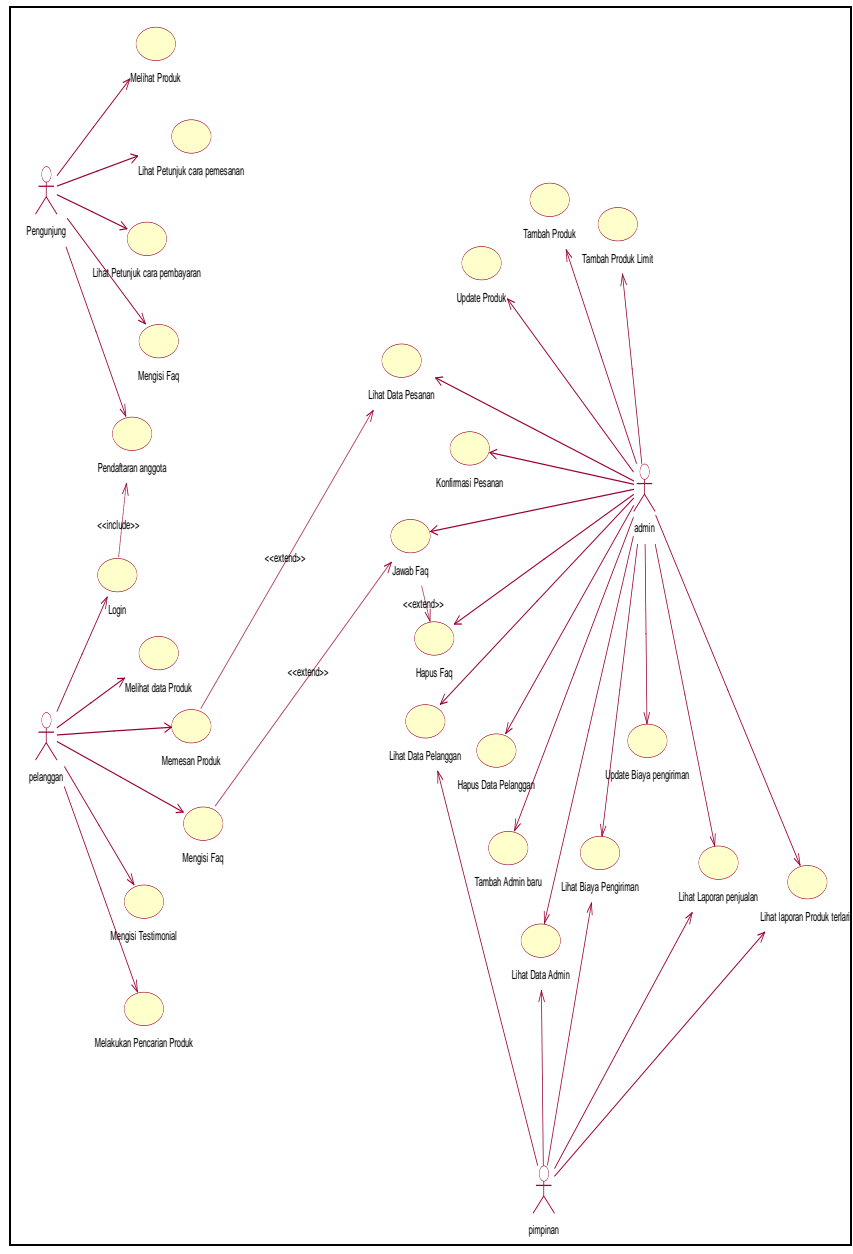

Gambar 1. Usecase Diagram

2) Activity Diagram Pendaftaran anggota

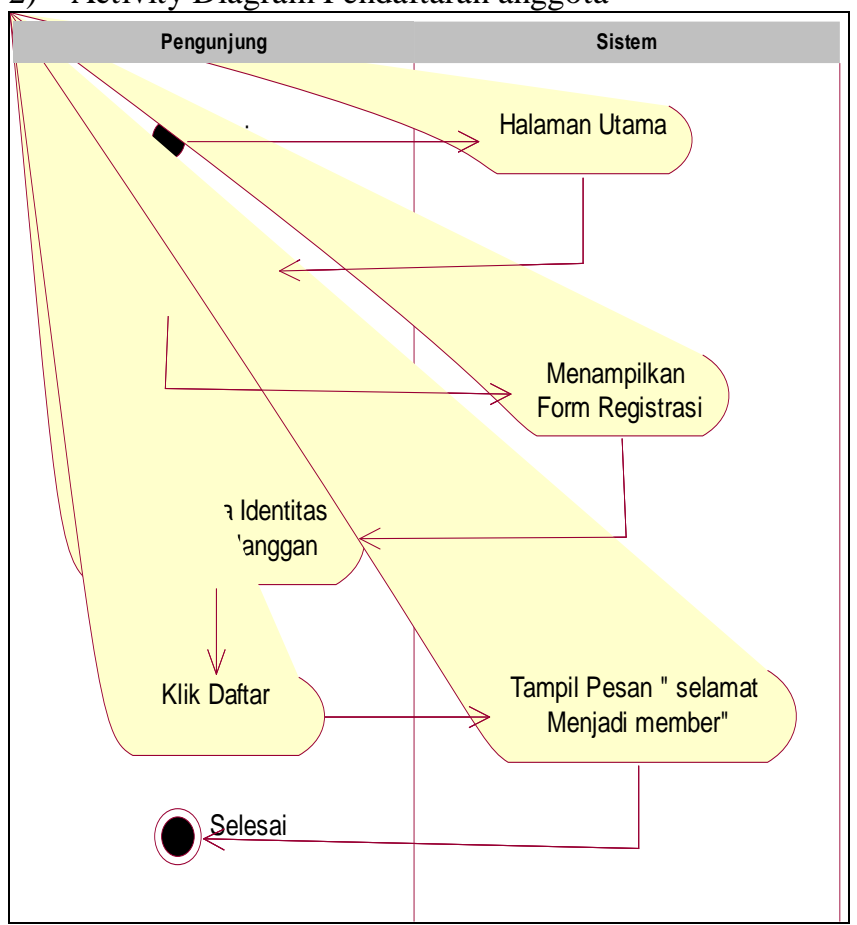

Gambar 2. Activity Diagram Pendaftaran anggota 
3) Activity Diagram Pemesanan

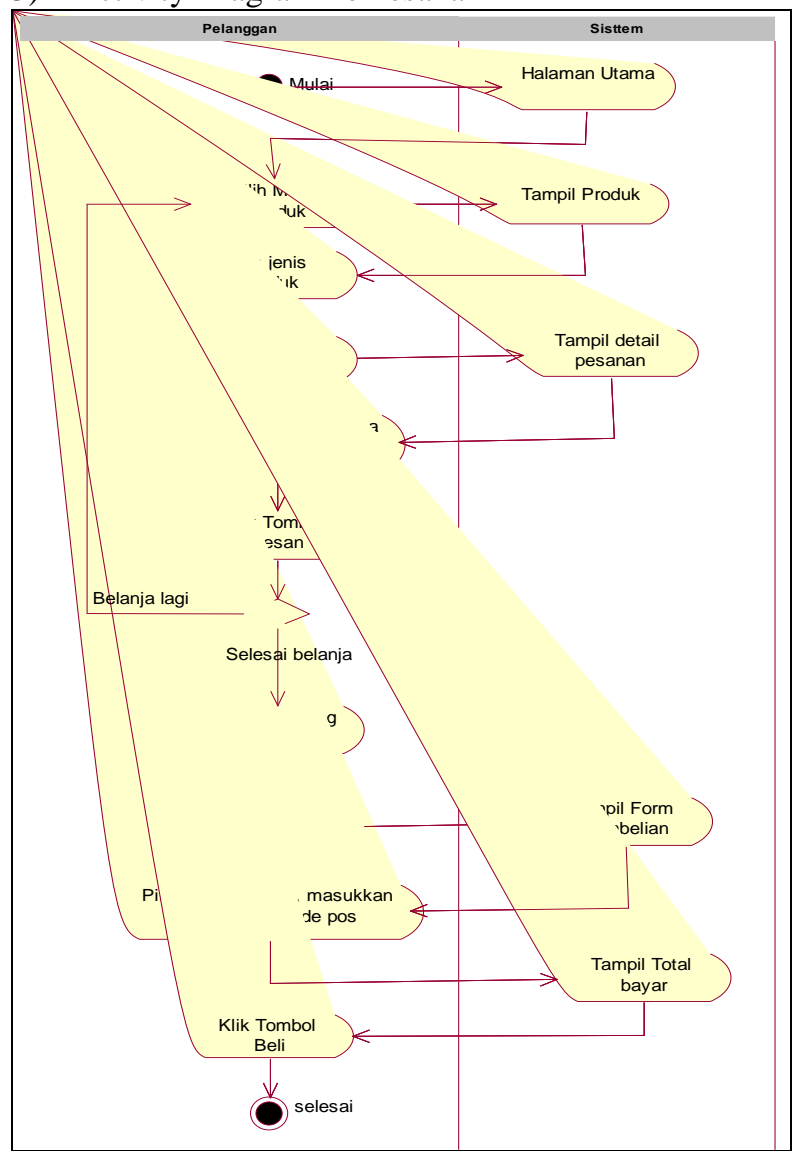

Gambar 3. Activity Diagram Pemesanan

4) Activity Pembayaran

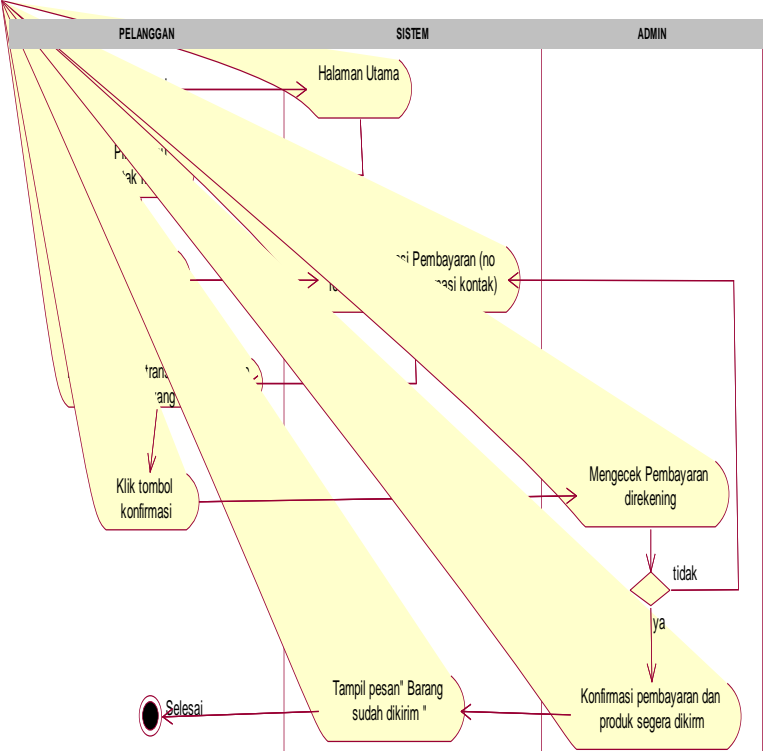

Gambar 4. Activity Pembayaran

\section{5) Class Diagram}

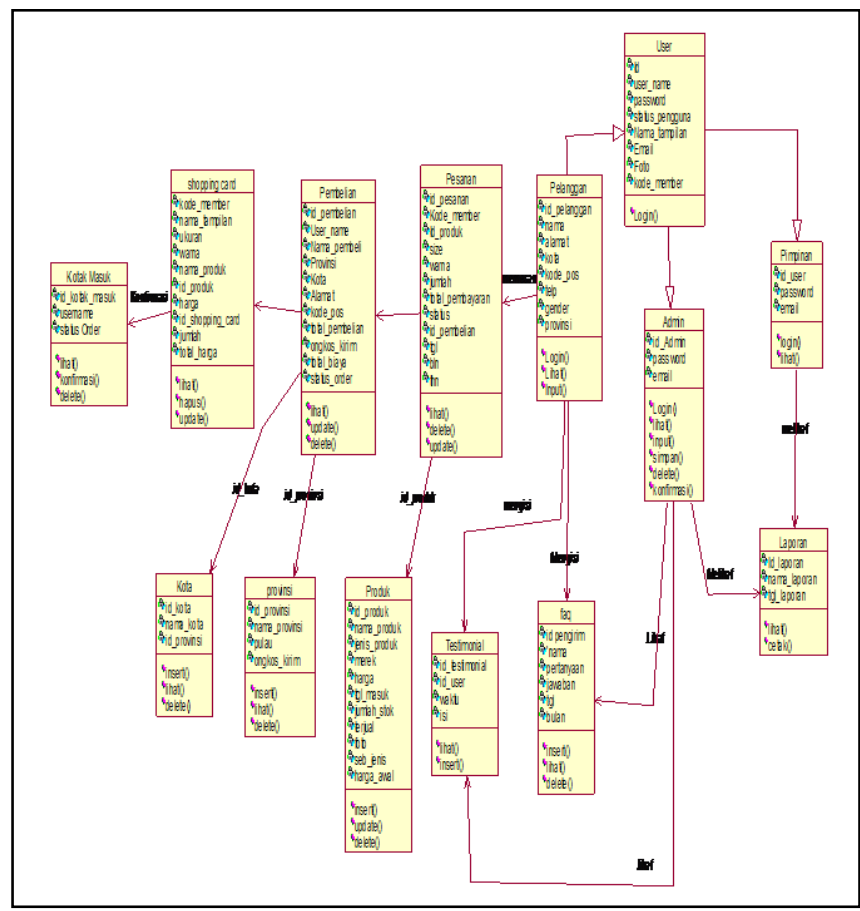

Gambar 5. Class Diagram

\section{E. Desain}

1) Arsitektur Sistem

Dibawah ini adalah arsitektur sistem atau diagram blok dari website penjualan dan pembelian pada gudang distro Palembang

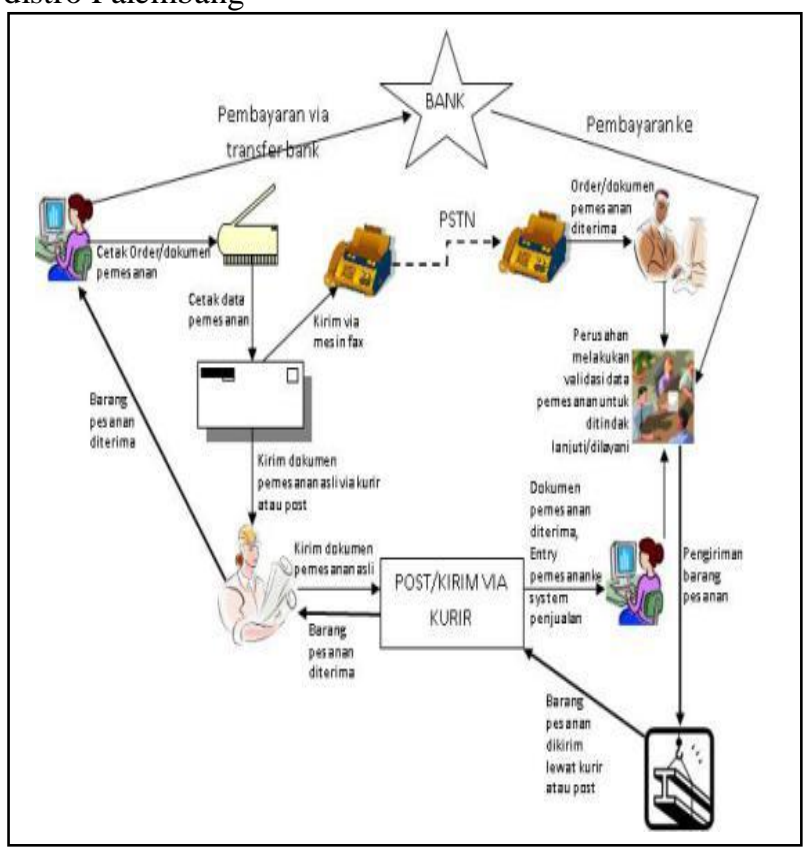

Gambar 6. Arsitektur Sistem 


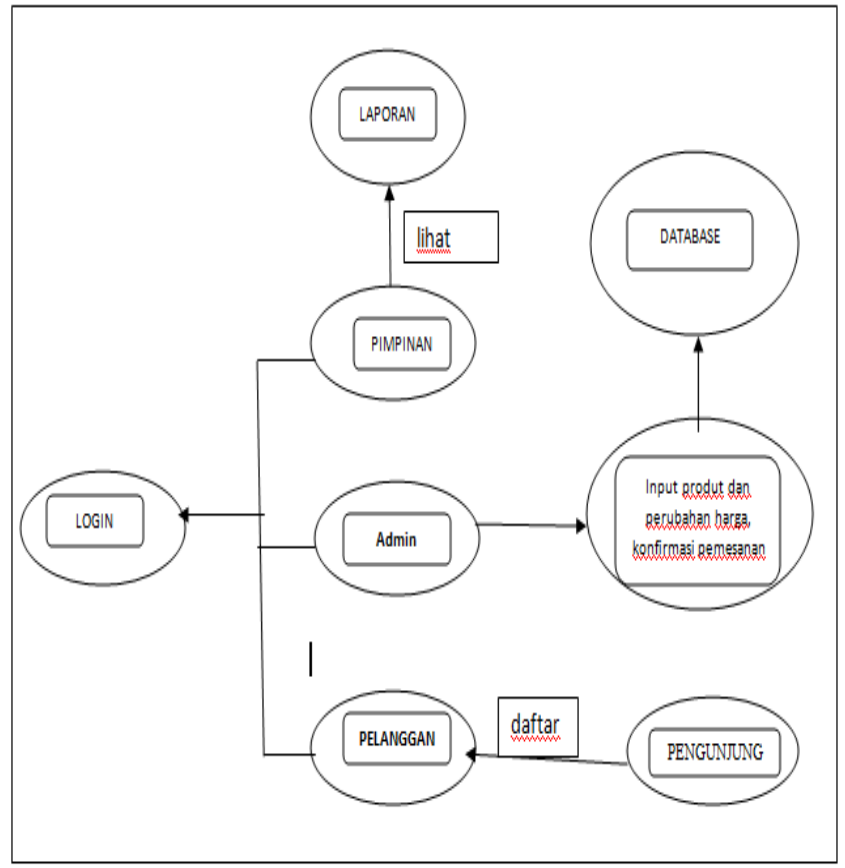

Gambar 7. Refresentasi aliran data

dalam website penjualan dan pembelian pada gudang distro palembang ada beberapa komposisi sebagai berikut :

a) Komposisi bagin login yang diggunakan untuk masuk dalam halaman homepage pelanggan, admin dan homepage pimpinan yang mennggunakan usename dan password yang diperoleh dari input data user dan ketika pelanggan mendaftar.

b) Komposisi bagian homepage pelanggan, didalam homepage pelanggan ada beberapa bagian yang berfungsi sesuai dengan fungsinya yaitu lihat produk, pesan produk, input faq, input testimonial, konfirmasi pembayaran.

c) Komposisi bagian homepage admin, dalam homepage admin ada beberapa bagian yang befungsi sesuai dengan fungsinya yaitu Input produk baru, edit data produk, tambah produk limit, input data admin, hapus data admin, input data pelanggan, hapus data pelanggan, input biaya pengiriman, konfirmasi pesanan, lihat produk terlaris, tambah stok produk terlaris, melihat dan cetak Laporan Penjulan.

d) Komposisi bagian homepage pimpinan, dalam homepage pimpinan ada beberapa bagian yang befungsi sesuai dengan fungsinya yaitu lihat data pelanggan, lihat data admin, lihat produk terlaris, lihat dan cetak laporan penjualan, lihat biaya pengiriman.

\section{PEMBAHASAN}

\section{A. Home Pengunjung}

Tampilan menu utama bagian admin merupakan tampilan ketika username dan password di isi dan benar
Jurnal SISFOKOM, Volume 05, Nomor 01, Maret 2016

oleh admin gudang distro palembang, Tampilan menu seperti dibawah ini

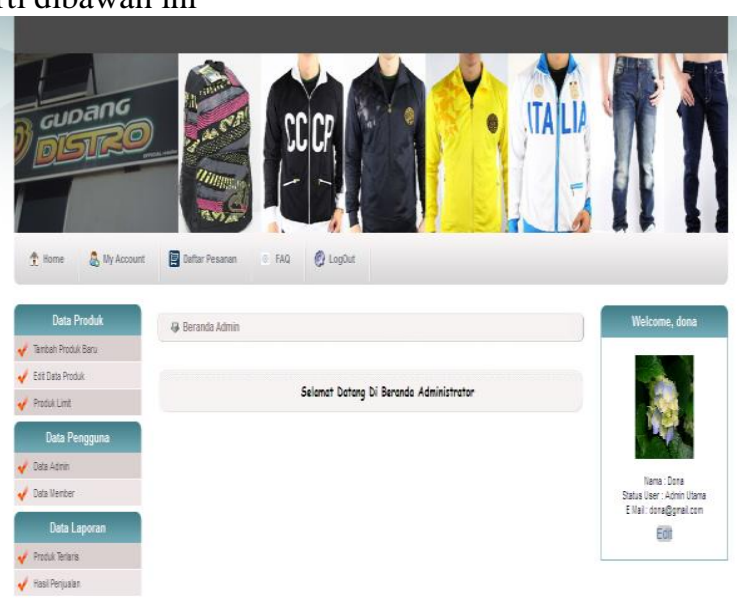

Gambar 8. Halaman Home Pengunjung

\section{B. All Produk}

Tampilan halaman all_produk berfungsi untuk menampilkan semua produk-produk yang di jual oleh gudang distro Palembang, Tampilan seperti dibawah ini.

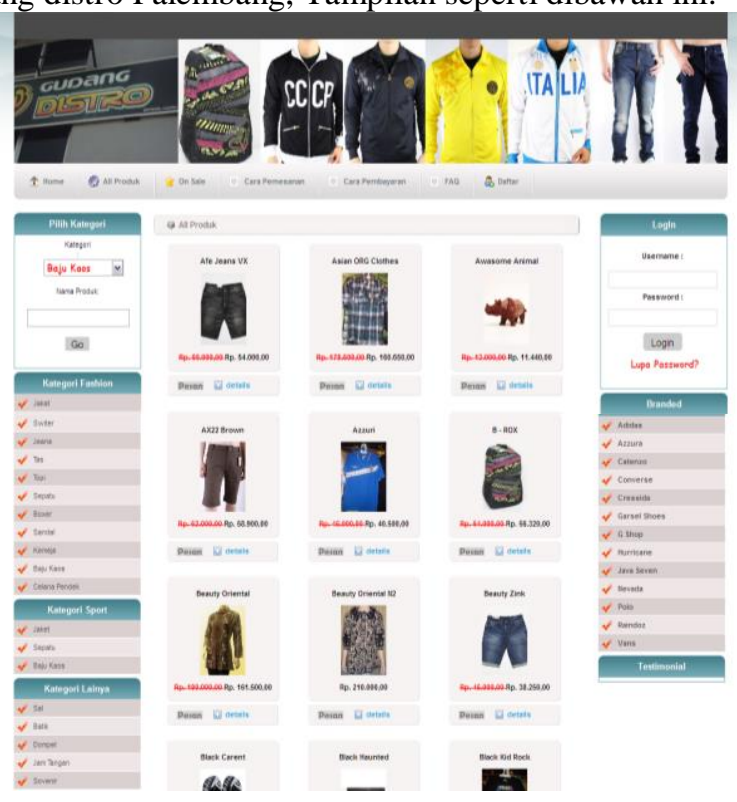

Gambar 9. Halaman All Produk

\section{Tampilan FAQ}

Tampilan halaman FAQ berfungsi untuk pengunjung mengisi pertanyaan yang akan di tanyakan kepada admin gudang distro Palembang, serta menampilkan pertanyaan pengunjung maupun pelanggan gudang distro palembang. 


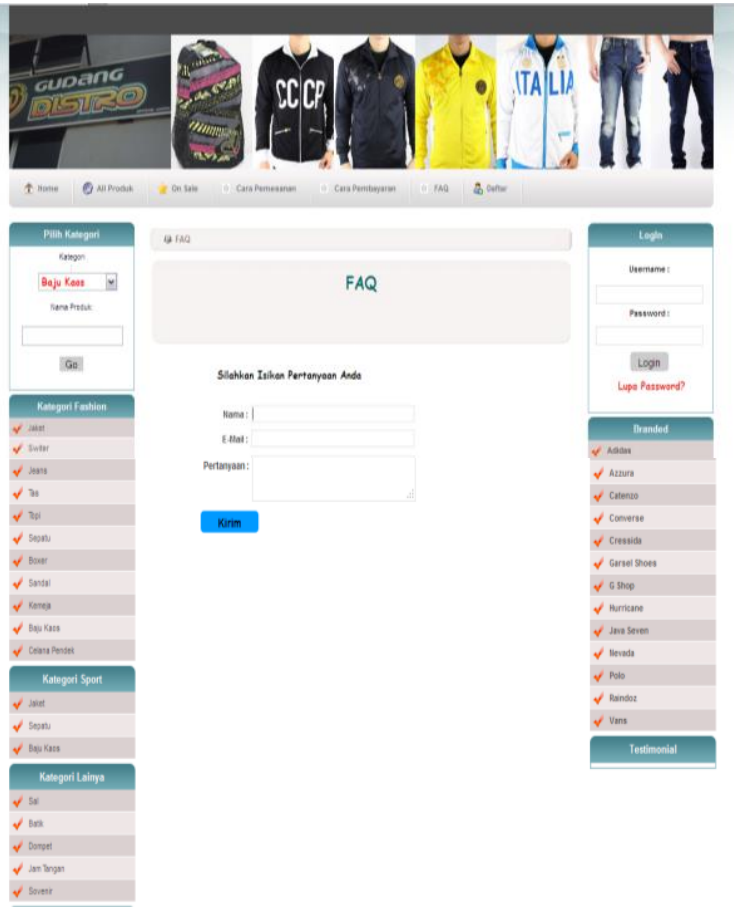

Gambar 10. Halaman FAQ

\section{Daftar Pelanggan}

Tampilan halaman Daftar berfungsi untuk pengunjung mendaftar sebagai pelanggan gudang distro Palembang, setelah pengujung mendaftar dan telah menjadi pelanggan, baru lah pengunjung bisa login dan bisa melakukan pemesanan produk.

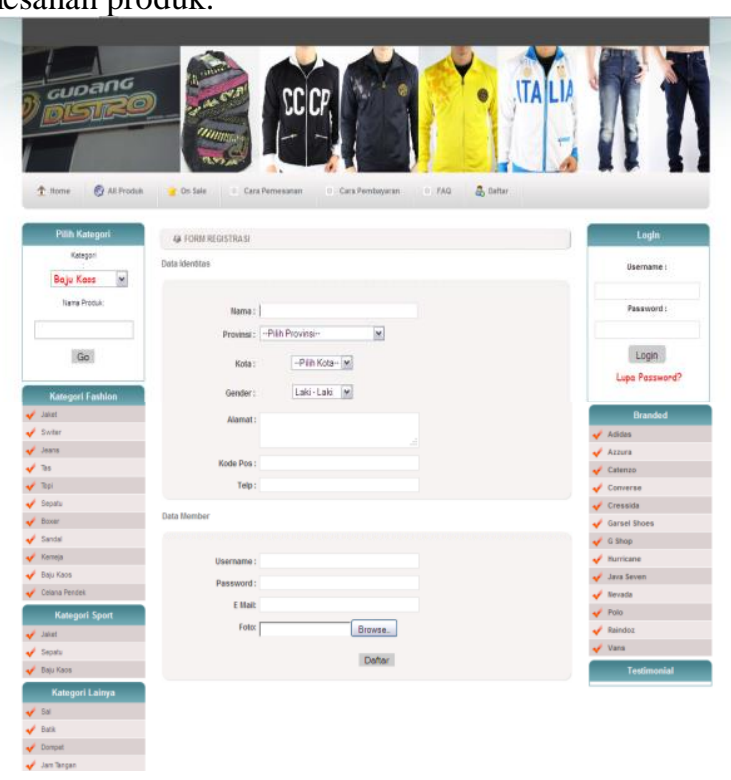

Gambar 11. Daftar Pelanggan

\section{E. Pesan Produk}

Tampilan halaman pesan produk berfungsi untuk menampilkan detail produk yang akan dipesan, dari ukuran, warna, serta jumlah produk yang mau dipesan pada gudang distro Palembang. Tampilan seperti gambar dibawah ini.

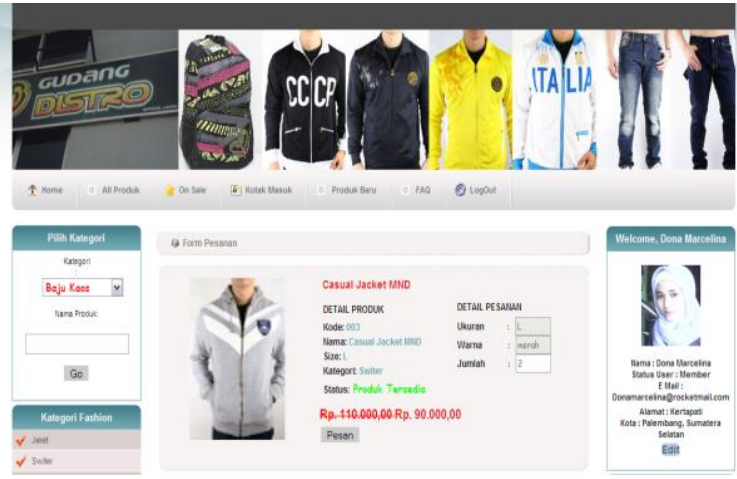

Gambar 12. Halaman Pesan Produk

\section{F. Status Pemesanan}

Tampilan Halaman status pesanan berfungsi untuk menampilkan status pesanan pelanggan produk sudah dikirim atau belum dikirim yang dikonfirmasi oleh administrator gudang distro Palembang,. Tampilan seperti gambar dibawah ini.

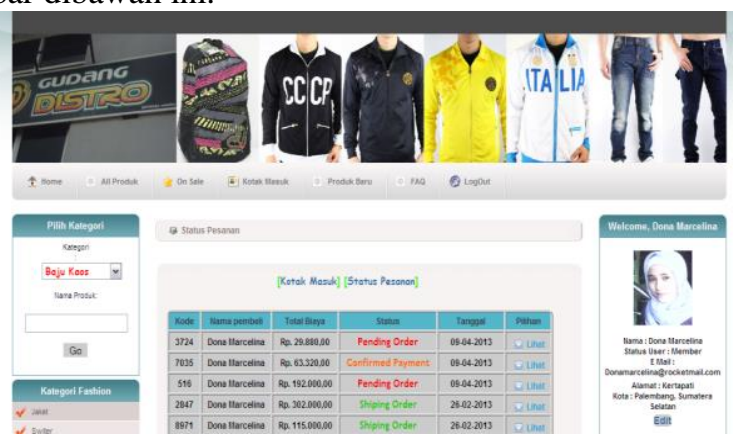

Gambar 13. Halaman Status Pemesanan

\section{G. Add Testimoni}

Tampilan halaman testimonial pelanggan berfungsi untuk pelanggan mengisi komentar kepada admin gudang distro Palembang, terhadap pengiriman produk, harga, jaminan mutu dll, serta halaman testimonial ini menampilkan komentar pengunjung maupun pelanggan gudang distro Palembang . Tampilan seperti gambar dibawah ini. 


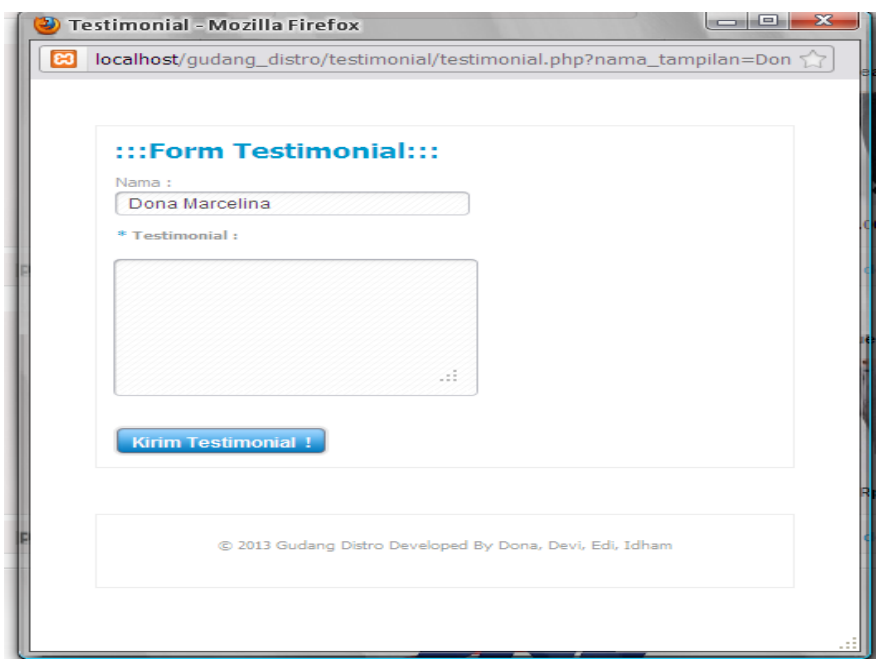

Gambar 14. Halaman Testimoni

\section{H. Tambah Produk}

Tampilan tambah produk baru untuk menginputkan produk yang dijual pada gudang distro palembang. Seperti gambar berikut ini.
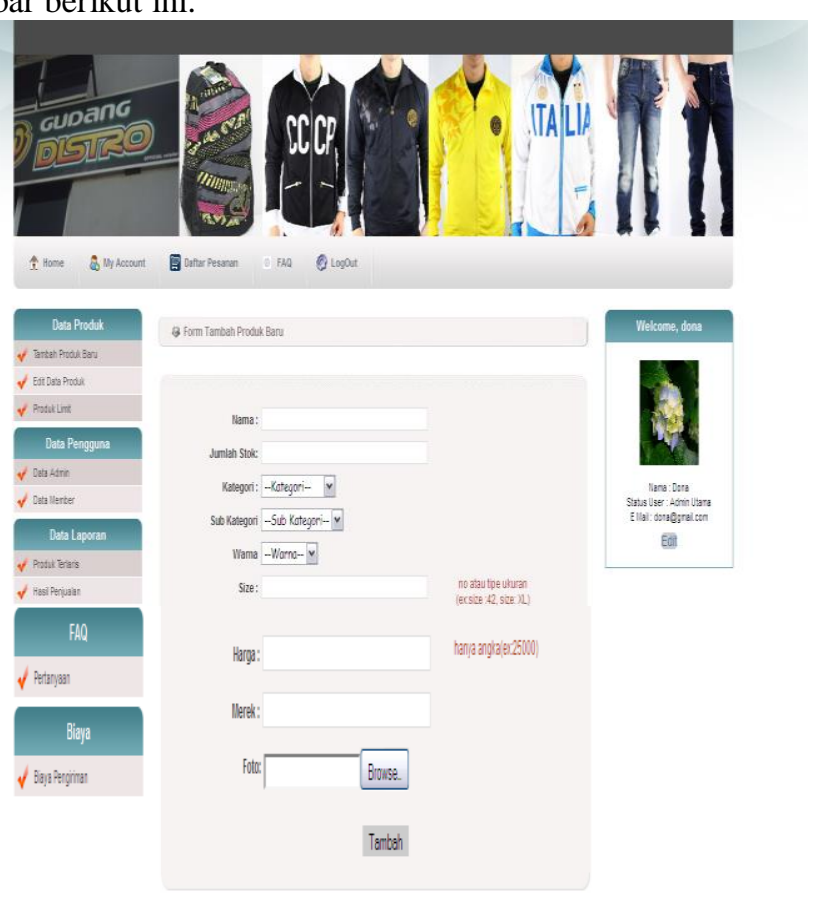

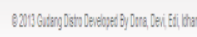

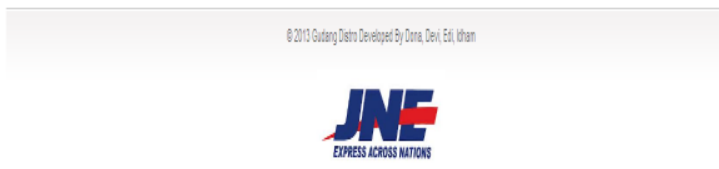

Gambar 15. Halaman Tambah Produk

\section{Data Costumer}

Tampilan Halaman Data member berfungsi untuk Administrator Melihat, Menambah dan menghapus data pelanggan yang ada pada gudang distro Palembang. Seperti gambar berikut ini.

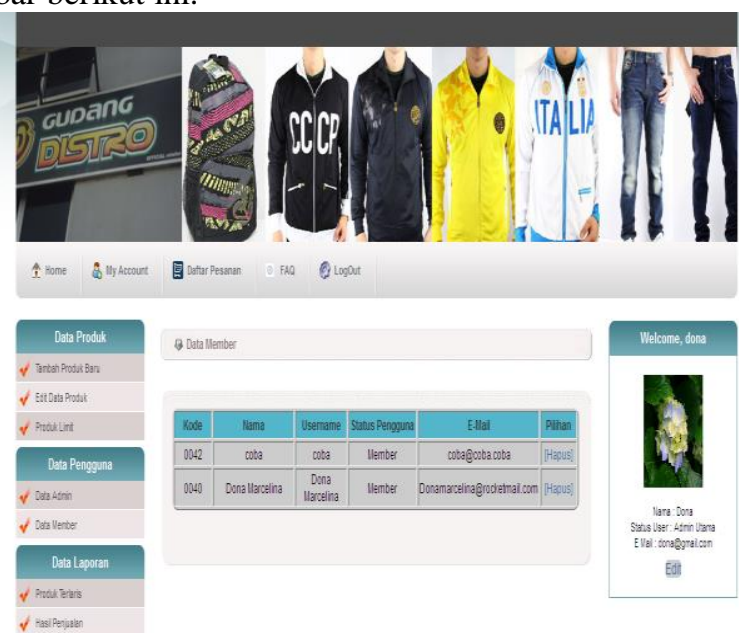

Gambar 16. Halaman Data Cunsomer

\section{J. Laporan Hasil Penjualan}

Tampilan Halaman Laporan Hasil Penjualan berfungsi untuk Admin melihat hasil laporan penjualan pada sistem informasi penjualan dan pembelian gudang distro Palembang. Laporan penjualan yang ditampilkan dapat dalam bentuk laporan penjualan harian, laporan penjualan bulanan atau laporan penjualan tahunan. Data yang ditampilkan dalam laporan hasil penjualan yaitu nama produk yang dibeli, jumlah, harga satuan, total biaya kemudian jumlah total hasil penjualan nya. Laporan hasil penjualan juga dapat dicetak. Seperti gambar dibawah ini.

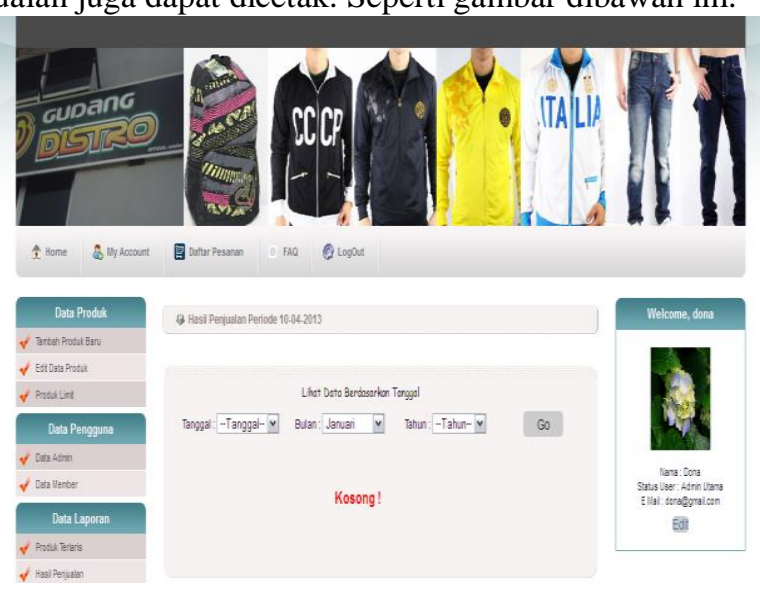

Gambar 17. Halaman Laporan Hasil Penjualan

\section{PENUTUP}

Kesimpulan dari Sistem ini adalah:

- Penggunaan sistem ini mudah di gunakan oleh pelanggan.

- Dengan penerapan CRM pada sistem ini, membuat sistem lebih menarik dan mudah di gunakan oleh pelanggan. 


\section{DAFTAR PUSTAKA}

[1] Buttle, F. Customer Relationship Management ( $2^{\text {nd }}$ ed). Burlington: Elsevier Ltd. 2009.

[2] Adelia dan Jimmy Setiawan. Jurnal: Implementasi Customer Relationship Management (CRM) pada Sistem Reservasi Hotel Berbasis Website dan Desktop. Maranatha University Press: Bandung. 2011.

[3] Rosa, M Shalahuddin. Rekayasa Perangkat Lunak Terstruktur dan Berorientasi Objek. Modula: Bandung. 2011.

[4] Dyantina, Ovi, dkk. Jurnal: Penerapan Customer Relationship Management (CRM) Berbasis Web Studi Kasus pada Sistem Informasi Pemasaran di Toko Yen-Yen. Jurnal Sistem Informasi Unsri. Palembang. Vol 4 No 2 Oktober 2012.

[5] Kumar, Reinartz Werner. Customer Relationship Management Concept, Strategy, and Tools Second Edition. Springer-Verlag Berlin Heidelberg: 2012. 